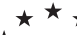

$\star$ Polityki Europejskie.

$\star$ Finanse i Marketing

$\star \star \star 16(65) 2016$

Marian Oliński

Uniwersytet Warmińsko-Mazurski w Olsztynie

Piotr Szamrowski

Uniwersytet Warmińsko-Mazurski w Olsztynie

\title{
Potencjal dialogowy witryn internetowych organizacji pożytku publicznego - podejście relacyjne
}

\author{
DIALOGIC FEATURES OF PUBLIC BENEFIT \\ ORGANIZATIONS WEBSITES - RELATIONAL \\ APPROACH
}

\begin{abstract}
Obecny zasięg $i$ znaczenie Internetu, daje ponadprzeciętne możliwości, odnośnie budowania relacji między interesariuszami a organizacjami non-profit. Dlatego celem niniejszego artykutu jest identyfikacja sposobu, w jaki organizacje pożytku publicznego (OPP) wykorzystuja witryny internetowe do budowy potencjatu dialogowego z jej użytkownikami.

$Z$ przeprowadzonych badań wynika (tacznie przebadano 367 organizacji pożytku publicznego), iz OPP $w$ niewielkim stopniu wykorzystuja tzw. pięć zasad w budowie potencjatu dialogowego witryny internetowej (zwłaszcza $w$ odniesieniu do elementów bezpośrednio tworzqcych potencjat dialogowy witryny internetowej). Wyraźnie brakuje także świadomości u osób odpowiedzialnych za podejmowanie decyzji w organizacjach pożytku publicznego, jak ważna role odgrywa obecnie public relations $w$ budowaniu relacji oraz w jaki sposób można w tym celu skutecznie wykorzystać Internet. $W$ niniejszym artykule wykorzystano metodę analizy publikowanych treści, stanowiqca jeden $z$ głównych typów tzw. analizy zawartości (content analysis).
\end{abstract}

Słowa kluczowe: organizacja pożytku publicznego, dialog, relacje, Internet

Wstęp

Pojawienie się Internetu na początku lat dziewięćdziesiątych XX wieku', zrewolucjonizowało mechanizm porozumiewania się, w znaczący sposób wpływając na funkcjonowanie całych społeczeństw. Przez ponad dwadzieścia lat istnienia, Internet wyraźnie „dojrzał”, stając się medium szeroko dostępnym. Obecnie stanowi globalną sieć łączącą miliony komputerów, urządzeń i ludzi, służąc zarówno celom prywatnym, publicznym, biznesowym, rządowym i naukowym. Niezaprzeczalnie jest również źródłem najbogatszych i najrozmaitszych informacji, zasobów i usług. Według prognozowanych danych z 1 lipca 2016 roku$^{2}$, ponad 3,4 miliarda ludności całego świata

\footnotetext{
${ }^{1}$ W 1992 roku została napisana pierwsza graficzna przeglądarka WWW o nazwie Mosaic, trzy lata później na bazie jej kodu zaprezentowano nową przeglądarkę internetową - Internet Explorer

${ }^{2} \mathrm{http} / /$ www.internetlivestats.com/internet-users/ (dostęp 13.06.2016).
} 
będzie miało dostęp do połączenia internetowego (około $40 \%$ łącznej populacji) ${ }^{3}$, a jeszcze w roku 1995 było to mniej niż 1\%. Liczba osób z dostępem do Internetu na przestrzeni 20 lat od roku 1993 do 2013 zwiększyła się dziesięciokrotnie. Pierwszy miliard osiagnięto w roku 2005, drugi w 2010, a trzeci w roku 2014. Chiny, kraj z największą liczbą użytkowników Internetu (642 miliony osób w roku 2014), stanowi $22 \%$ łącznej liczby użytkowników sieci. Polsce w tej klasyfikacji przypadło 24 miejsce z prawie 26 milionami osób z dostępem do Internetu, co stanowi niecałe $67 \%$ populacji kraju.

Znaczenie, jakie odgrywa obecnie Internet spowodowało, że wszelkiego rodzaju organizacje zaczęły dostrzegać szansę jaką daje on w angażowaniu jego użytkowników w dwustronne interakcje, stanowiąc opozycję do dotychczasowego modelu opartego na jednostronnym przekazie informacji. Liczni autorzy wskazują na rosnące znaczenie tego medium w Public Relations (PR). Już w roku 1996 Gustafson i Thomsen prognozowali, że praktycy PR poświęcać będą zdecydowanie więcej czasu na komunikowanie się on-line $\mathrm{z}$ klientami, mediami czy po prostu użytkownikami Internetu ${ }^{4}$. Internet wzmacnia bowiem nie tylko siłę przetargową interesariuszy, ale także zdolność organizacji do zbierania informacji, monitorowania opinii publicznej oraz angażowania się $\mathrm{w}$ bezpośredni dialog $\mathrm{z}$ użytkownikami strony $\mathrm{WWW}^{5}$. Liczne badania w tym zakresie, przeprowadzane zwłaszcza w krajach anglosaskich, dotyczyły głównie analizy cech witryn internetowych ${ }^{6}$, identyfikacji potencjału jaką witryna WWW czy media społecznościowe moga posiadać w budowaniu i utrzymaniu relacji z jej użytkownikami ${ }^{7}$, czy jej roli w zarządzaniu kryzysowym i budowaniu wizerunku ${ }^{8}$.

\footnotetext{
${ }^{3}$ Liczba osób z dostępem do internetu w miejscu zamieszkania, bez uwzględnienia osób użytkujących internet poza nim oraz częstotliwości jego użytkowania. Dane historyczne oraz prognozowane uzyskano w oparciu o „Worldometers' RTS” algorytm, który analizuje dane z takich źródeł jak: International Telecommunication Union (ITU) - oficjalne źródło światowych danych z zakresu ICT, ICT Facts and Figures - The world in 2015 - ITU, Measuring the Information Society - ITU MIS Report 2015, Internet Users Data - World Bank Group, The World Factbook: Internet Users - U.S. Central Intelligence Agency, United Nations Population Division U.N. Department of Economic and Social Affairs

${ }^{4}$ R.L. Gustafson \& S.R. Thomsen: Merging the teaching of public relations and advertising onto the information superhighway. Public Relations Quarterly, 41(1)/1996, s. 38-42.

${ }^{5}$ S. McAllister \& M. Taylor.: Community college Web sites as tools for fostering dialogue. Public Relations Review 33/2007, s. 230-232; R. Van der Merwe, L. Pitt \& R. Abratt: Stakeholder strength: PR survival strategies in the Internet age. Public Relations Quarterly 50(1)/2005, s. 39-48.

${ }^{6}$ S. Rybalko, T. Seltzer: Dialogic communication in 140 characters or less: How Fortune 500 companies engage stakeholders using Twitter, Public Relations Review Vol. 36 (4)/2010, s. 336-341; H. Park, B.H. Reber: Relationship building and the use of Web sites: How Fortune 500 corporations use their Web sites to build relationships, Public Relations Review 34/2008, s. 409-411; S.L. Esrock \& G.B. Leichty: Organization of corporate Web pages: Publics and functions. Public Relations Review, 26/2000, s. 327-344.

${ }^{7}$ R.E. Hinson, H. van Zyl, S. Agbleze: An interrogation of the dialogic potential of insurance firm websites in Ghana, Information Development 1-11/2013; K. Lovejoy, G.D. Saxton: Information, Community, and Action: How Nonprofit Organizations Use Social Media, Journal of Computer-Mediated Communication Vol. 17/2012, s. 337-353; K. Lovejoy, R.D. Waters, G.D. Saxton: Engaging stakeholders through Twitter: How non-profit organizations are getting more out of 140 characters or less, Public Relations Review vol. 38(2)/2012, s. 313-318; D. Ingenhoff \& A.M. Koelling: The potential of Web sites as a relationship building tool for charitable fundraising NPOs. Public Relations Review 35/2009, s. 66-73; Bortree, \& Seltzer: Dialogic strategies and outcomes: an analysis of environmental advocacy groups' Facebook profiles. Public Relations Review, 35/2009, s. 317-319; M. Taylor, M.L. Kent \& W.J. White: How activist organizations are using the Internet to build relationships, Public Relations Review,27(3)/2001, s. 63-77.
} 
Badania te obejmowały organizacje o bardzo zróżnicowanych charakterystykach, poczynając od tych o charakterze komercyjnym (głównie przedsiębiorstw), poprzez organizacje non-profit, uniwersytety czy witryny internetowe organizacji o charakterze politycznym.

Niniejszy artykuł wpisuje się w omawianą problematykę. Jego celem jest bowiem identyfikacja sposobu, w jaki organizacje pożytku publicznego wykorzystują witrynę WWW do budowy potencjału dialogowego („dialogic communication”) z jej użytkownikami. Wśród nich będą użytkownicy o różnym znaczeniu dla organizacji, tj. media, samorząd terytorialny, sponsorzy, wolontariusze czy obecni i potencjalni darczyńcy. Rodzima literatura naukowa jest $\mathrm{w}$ tym zakresie bardzo skromna, brakuje opracowań dotyczących wykorzystania Internetu przez organizacje non-profit i roli jaką odgrywają witryny internetowe tych organizacji w budowaniu i utrzymywaniu relacji z jej użytkownikami. Niniejszy artykuł ma na celu częściowe wypełnienie tej luki. Stanowi on część większego projektu badawczego, który oprócz analizy potencjału dialogowego stron WWW obejmuje swoim zakresem określenie roli, jaką pełnią social media w praktyce Public Relations polskich organizacji non-profit. Autorzy w swoich badaniach koncentrowali się przede wszystkim na tych cechach witryny, które ułatwiają dwustronną symetryczną komunikację (two-way symmetrical communication), budując w ten sposób jej „dialogowy” potencjał, choć w badaniach starano się unikać błędu zrównującego ten rodzaj komunikacji organizacji z otoczeniem z rozumieniem dialogu per se. Dialog bowiem w każdym przypadku obejmuje dwustronną komunikację, natomiast nie każda dwustronna komunikacja ten dialog stanowi. Przykładowo więc, jeśli konkretna witryna organizacji non-profit cechuje się wysokim "dialogowym” potencjałem (cechami ułatwiającymi dwustronną symetryczną komunikację) to wcale nie oznacza, że dialog między użytkownikiem witryny, a organizacją faktycznie istnieje.

Wydawać by się mogło, że termin „dialog” jest pojęciem jasnym i powszechnie zrozumiałym. Jednakże znawcy tematu, tacy jak np. Bokeno przyznaja, że wciąż brakuje zwięzłej $\mathrm{i}$ jasnej jego definicji ${ }^{9}$. Jest to bowiem pojęcie złożone, interdyscyplinarne, postrzegane $\mathrm{z}$ jednej strony jako narzędzie ${ }^{10}$, bądź jako proces ${ }^{11}$ lub jako rezultat ${ }^{12}$. Jego znaczenie analizowano już w czasach starożytnych, natomiast w czasach współczesnych wzrost zainteresowania tym terminem datuje się na drugą połowę XX wieku, co związane jest $\mathrm{z}$ takimi nazwiskami jak Bakhtin, Bohm, Buber, Gadamer i Rogers ${ }^{13}$.

\footnotetext{
${ }^{8}$ A.M. DiNardo: The Internet as a crisis management tool: A critique of banking sites during Y2K. Public Relations Review, 28/2002, s. 367-378; C.F. Greer \& K.D. Moreland: United Airlines' and American Airlines' online crisis communication following the September 11 terrorist attacks. Public Relations Review, 29/2003, s. 427-441.

${ }^{9}$ M. Bokeno: Dialogue at work? What it is and isn't. Development and Learning in Organizations, 21(1)/2007, s. 9-11.

${ }^{10}$ S.A. Lord: Meditative dialogue: A tool for engaging students in collaborative learning processes. Journal of Family Therapy 29(4)/2007, s. 334; K. Morrell: Socratic dialogue as a tool for teaching business ethics. Journal of Business Ethics 53(4)/2004, s. 383-392.

${ }^{11}$ M. Blank \& E. Franklin: Dialogue with preschoolers: A cognitively-based system of assessment. Applied Psycholinguistics, 1(02)/2008, s. 127-150; C. Grönroos: The relationship marketing process: communication, interaction, dialogue, value. The Journal of Business and Industrial Marketing, 19(2)/2004, s. 99-113.

${ }^{12}$ B. Herzberg \& A. Wright: The public-private dialogue handbook: a toolkit for business [sic] environment reformers, 2006, Retrieved from http://www.publicprivatedialogue.org/tools/PPDhandbookC7.pdf

${ }^{13}$ M. Bakhtin: The dialogic imagination: four essays by M. M. Bakhtin (C. Emerson \& M. Holquist, Trans.).:

University of Texas Press., Austin, Texas 1981; D. Bohm: Unfolding meaning: A weekend of dialogue with
} 
Wskazują oni na trzy kluczowe elementy składające się na „dialog”, tj. pragnienie uczestników do porozumiewania się między sobą, sam proces komunikacji dialogowej oraz jego rezultat. W przypadku pierwszego elementu uczestnicy dialogu rozumieją istnienie współzależności komunikujących się stron, respektują prawo innych osób do wyrażania swoich opinii i poglądów oraz szukają dla nich zrozumienia. W fazie wdrożenia dialogu uczestników powinna cechować wrażliwość, elastyczność, prawdomówność i jasność w przedstawianiu swojego stanowiska. Ponadto w tej fazie osoby komunikujące się powinny rozumieć fakt, że inna osoba może mieć odmienny punkt widzenia. Istotne w tej fazie jest również to, że osoby komunikujące się ze sobą są względem siebie równe i każdy dysponuje podobną siła przetargową. Fazę trzecią, wynikową cechuje wzajemne zrozumienie, szacunek, troska i zainteresowanie oraz współdzielenie władzy. Z kolei Pieczka po analizie literatury przedmiotu wskazuje na osiem kluczowych cech charakteryzujących dialog, tj. ${ }^{14}$ :

- rozciągnięty w czasie nieciągły proces, w dających się rozdzielić częściach;

- obejmujący dwustronną komunikację, dotyczący kwestii ważnych dla obu stron;

- uczestnicy dialogu są świadomi różnic w poglądach, nie może istnieć „dialog” w sytuacji kiedy jego uczestnicy mają podobny lub taki sam punkt widzenia. Stanowiska uczestników cechuje „ładunek emocjonalny”;

- „dialog” nie jest jedynie „wymianą poglądów”, nie jest tylko kwestią wiedzy co myślą pozostali uczestnicy procesu, ale zrozumienia „, jak oni myślą”;

- uczestnicy nie starają się wyeliminować wszystkich różnic dzielących uczestników i osiągnąc zbliżony tok rozumowania. Oczekuje się raczej, że uczestnicy znajdą wspólną płaszczyznę porozumienia, bez konieczności całkowitego przyjęcia punktu widzenia drugiej strony;

- od obu stron wymaga się postawy szacunku i dobrej woli;

- uczestnicy dialogu powstrzymują się wypowiadania kwestii krytycznych, które świadczą o celowym ,ataku” na drugą stronę (chyba, że uczestnik dąży do zaprzestania dialogu);

- uczestnicy traktują dialog jako wartościowy i produktywny per se.

W literaturze dotyczącej PR pojęcie dialogu przewija się $\mathrm{z}$ różną częstotliwością od ponad trzydziestu lat $\mathrm{i}$ wiąże się $\mathrm{z}$ zainicjowaną $\mathrm{w}$ połowie lat osiemdziesiątych perspektywą nastawioną na budowę relacji również w kontekście Public Relations (tzw. relational perspective of PR). Wcześniej narzędzia stosowane w PR miały na celu przede wszystkim osiaganie pożądanych przez kierownictwo celów, kierując się zasadą opartą głównie na manipulacji i nakłanianiu interesariuszy do podejmowania decyzji korzystnych $\mathrm{z}$ punktu widzenia organizacji. Dominowało podejście funkcjonalne, w którym odbiorcy przekazu traktowani byli przedmiotowo i pasywnie. Zmiana w podejściu do interesariuszy organizacji wiąże się z nadejściem lat

David Bohm., NY: Routledge New York 1985; M. Buber: I and Thou: Continuum Publishing Group Inc., 2004; H.G. Gadamer: Dialogue and dialectic: eight hermeneutical studies on Plato (P. C. Smith, Trans.)., CT: Yale University Press, New Haven 1980; Rogers, C. R.: On becoming a person : a therapist's view of psychotherapy.: Constable \& Company, London 1961.

${ }^{14}$ M. Pieczka: Public relations as dialogic expertise? Journal of Communication Management 15(2)/2011, s. 108-124. 
osiemdziesiątych, kiedy zaczęto ich traktować jako jednostki niezależne, dysponujące dużą siłą przetargową w kontekście tworzenia organizacyjnej wartości. Public relations zaczęto traktować jako funkcję zarządzania, która ustanawia i utrzymuje wzajemnie korzystne stosunki pomiędzy organizacją i różnymi grupami jej otoczenia, od których zależy jej sukces lub niepowodzenie ${ }^{15}$. Pojawienie się w naukach o zarządzaniu relacyjnego paradygmatu oznaczało, traktowanie organizacji, jako nierozerwalnie związanych z interesariuszami. Interesariusze byli w tym układzie partnerami w dazżeniu do realizacji organizacyjnych celów ${ }^{16}$. Relacyjne podejście $w$ naukach o zarządzaniu wiązało się ze zwiększonym zainteresowaniem takimi strategiami komunikacji, które pozwalałoby na osiagnięcie obopólnych korzyści na linii organizacja - interesariusze. Dialog stał się w tym momencie wyborem najwłaściwszym, zwłaszcza w kontekście dwóch z czterech modeli PR zaproponowanych przez Gruniga i Hunta ${ }^{17}$. Za najlepszy uznano wybór symetrycznej, dwustronnej komunikacji, traktując komunikację jednostronną (monolog) jako nieefektywny z punktu widzenia celów organizacji i Public Relations. Wielu autorów ${ }^{18}$. Theunissen i Wan Noordin tylko tę formę traktowali jako możliwą do budowy dialogu (jej asymetryczną formę utożsamiając $\mathrm{z}$ perswazja, immanentnie nieetyczną - dialog rozumiany jest jako najbardziej etyczna forma komunikacji $^{19}$. Dodatkowo, znaczenie dwustronnej, symetrycznej komunikacji ugruntowało pojawienie się Internetu, który umożliwił organizacjom budowę nowego kanału do komunikowania się z jego użytkownikami. Publikowanie treści w internecie czy to poprzez witrynę WWW czy z wykorzystaniem mediów społecznościowych stało się nowym narzędziem public relations. Organizacje zaczęły dostrzegać szansę, jaką daje Internet $\mathrm{w}$ angażowaniu jego użytkowników $\mathrm{w}$ dwustronne interakcje, stanowiąc opozycję do modelu opartego na jednostronnym przekazie informacji wykorzystywanym przez pracowników odpowiedzialnych za Public Relations i marketing. Wraz z rozwojem Internetu autorzy tacy jak Kent i Taylor zaczęli traktować dialog (dialogic communication), jako niezależny teoretyczny konstrukt o dużym znaczeniu dla public relations. W swojej przełomowej pracy z roku 1998 wskazali na związek między dwustronnym symetrycznym modelem PR Gruniga i Hunta, a komunikacją dialogową. Ten pierwszy traktowali jako proces, w którym celem działań PR organizacji jest dostarczenie narzędzi umożliwiających interaktywną komunikację między organizacją, a jej otoczeniem. Z kolei komunikacja dialogowa odnosi się wytworzonych na tej bazie relacji, w tym znaczeniu dialog traktowany jest raczej jako produkt, a nie proces ${ }^{20}$.

Internet wydaje się szczególnie użytecznym narzędziem w budowaniu relacji opartych na dialogu w organizacjach typu non-profit. Przeprowadzone do tej pory

\footnotetext{
${ }^{15}$ S.M. Cutlip, A.H. Center \& G.M. Broom: Effective public relations (9th ed.). Upper Saddle River, N.J.: Prentice Hall 2006.

16 J.E. Post, L.E. Preston \& S. Sauter-Sachs: Redefining the corporation: Stakeholder management and organizational wealth., CA: Stanford University Press, Stanford 2002.

17 J.E. Grunig: Organizations, environments and models. Public Relations Research and Education, 1(1)/1984, s. 6-29.

${ }^{18}$ K. Podnar \& U. Golob: Reconstruction of public relations history through publications in Public Opinion Quarterly. Management, 13(1)/2009, s. 55-76.

${ }^{19}$ P. Theunissen, W. Wan Noordin: Revisiting the concept "dialogue" in public relations, Public Relations Review, 38/2012, s. 5-13.

${ }^{20}$ M. L. Kent, \& M. Taylor: Building dialogic relationships through the World Wide Web. Public Relations Review, 24(3)/1998, s. 321-334.
} 
badania $\mathrm{w}$ tym zakresie, pokazały jednakże, że witryna WWW w przypadku tego rodzaju organizacji pełni przede wszystkim rolę informacyjną i rzadko kiedy jest wykorzystywana jako strategiczne, interaktywne narzędzie komunikacji służące do budowania $\mathrm{i}$ utrzymywania relacji $\mathrm{z}$ użytkownikami witryny ${ }^{21}$. Jest to $\mathrm{o}$ tyle niezrozumiałe, że witryna WWW daje organizacji możliwość komunikacji nie tylko z klientem (darczyńcami), ale również z wolontariuszami, mediami czy innymi jej użytkownikami. Witryna internetowa nie powinna w tym przypadku pełnić jedynie roli broszury informacyjnej, zwłaszcza w przypadku organizacji, które dysponują zazwyczaj niewielkim budżetem reklamowym. Dobrze zaprojektowana witryna internetowa staje się $\mathrm{w}$ tym momencie istotnym narzędziem $\mathrm{w}$ dostępie do bardzo zróżnicowanych odbiorców po stosunkowo niskim koszcie. Perspektywa obniżenia kosztów transakcyjnych w przypadku organizacji non-profit powinna więc być bardzo kusząca, nawet pomimo konieczności zdobycia technicznej wiedzy z zakresu projektowania witryn internetowych. Ponadto budowa w tego typu organizacjach relacji opartych na dialogu wydaje się szczególnie ważna, zwłaszcza jeśli mówimy o podmiotach, które uwypuklają w swojej misji współczucie i solidarność, a nie konkurencję i konsumpcjonizm. Organizacje non-profit stosować mogą bardzo zróżnicowany wachlarz narzędzi do komunikowania się z użytkownikami witryny WWW. Z jednej strony będą to narzędzia typowo informacyjne (one-way communication), jak choćby sposób wykorzystania środków finansowych pozyskanych od darczyńców, raporty finansowe dostępne na stronie świadczące o wiarygodności finansowej organizacji, informacje o misji, celach, programach, a z drugiej strony narzędzia bezpośrednio budujące potencjał dialogowy witryny, wpisujące się w dwustronny, symetryczny model Public Relations, takie jak: fora dyskusyjne, chaty, opcje dodawania komentarzy, możliwość wypełnienia kwestionariusza ankiety i głosowania on-line, blogi, itd. Oba rodzaje tych narzędzi tworzą platformę, na której organizacja non-profit może zbudować swój potencjał dialogowy.

\section{Metodyka badań}

Głównym celem badań jest identyfikacja sposobu w jaki organizacje pożytku publicznego wykorzystują witrynę WWW do budowy potencjału dialogowego (,,dialogic communication") z jej użytkownikami. Prezentowane badania są elementem szerszego projektu badawczego obejmującego zarządzanie relacjami w dobie społeczeństwa informacyjnego. $\mathrm{W}$ dalszej kolejności planuje się przeprowadzenie badań, związanych z wykorzystaniem mediów społecznościowych w komunikacji organizacji non-profit $\mathrm{z}$ otoczeniem. W oparciu o przegląd dostępnej literatury, prezentowane wyniki badań miały na celu odpowiedź na następujące pytania badawcze:

\footnotetext{
${ }^{21}$ R.E. Hinson, H. van Zyl, S. Agbleze: An interrogation of the dialogic potential of insurance firm websites in Ghana, Information Development 1-11/2013; D. Ingenhoff \& A.M. Koelling: The potential of Web sites as a relationship building tool for charitable fundraising NPOs. Public Relations Review 35/2009, s. 66-73; J. Gordon, S. Berhof: University websites and dialogic features for building relationships with potential students, Public Relations Review, 35/2009, s. 150-152; M.L. Kent, M. Taylor \& W. White: The relationship between Web site design and organizational responsiveness to stakeholders. Public Relations Review 29(1)/2003, s. 6377 .
} 
- W jakim stopniu organizacje non-profit wykorzystują pięć zasad w budowie potencjału dialogowego witryny internetowej, tj. „pętla” dialogowa”, użyteczność informacji dodatkowo $\mathrm{w}$ podziale na najistotniejsze kategorie, bodźce do ponownego odwiedzania witryny internetowej, funkcjonalność "interfejsu" użytkownika oraz utrzymanie użytkownika na witrynie internetowej organizacji?

- Czy organizacje non-profit w projektowaniu witryny internetowej kładą nacisk w większym stopniu na jej elementy techniczne czy te bezpośrednio związane z potencjałem dialogowym?

- Do jakiego rodzaju użytkowników kierowana jest główna uwaga przy projektowaniu witryny internetowej organizacji non-profit?

W badaniach wykorzystano zmodyfikowany dla potrzeb organizacji non-profit schemat kodowania witryn internetowych bazujący na pracy Taylora i Kenta ${ }^{22}$. Jest to pierwsze takie narzędzie w literaturze public relations wykorzystane do badania relacji między organizacją, a użytkownikami witryny WWW. Wskazują oni na 5 elementów, kluczowych w komunikacji dialogowej między organizacją, a użytkownikiem witryny WWW. Po pierwsze jest to tzw. ,pętla dialogowa”. Stanowi ona najważniejszy element $\mathrm{w}$ budowie potencjału dialogowego witryny WWW, bowiem nawet jeśli organizacja wdraża pozostałe cztery elementy, bez „pętli dialogowej”, jej możliwości w budowie dialogu są ograniczone. Ma ona umożliwić wystapienie tzw. sprzężenia zwrotnego u użytkownika witryny WWW. Ma ona więc skłonić go do kierowania zapytań czy komentowania publikowanych postów organizacji. Z drugiej strony sama organizacji za pośrednictwem administratora witryny może odpowiadać na komentarze użytkowników. W badaniach do budowy ,pętli dialogowej” wykorzystano takie elementy witryny jak opcja umieszczenia komentarza do publikowanych informacji, możliwość subskrypcji newslettera, istnienie blogów, czy dostęp do ogólnych informacji kontaktowych na stronie startowej.

Drugim elementem składającym się na potencjał dialogowy witryny jest użyteczność informacji. W przeprowadzonych badaniach element ten został zmodyfikowany i dostosowany do potrzeb organizacji non-profit. $Z$ jednej strony zachowano podział na informacje użyteczne dla ogółu użytkowników, z drugiej strony dokonano podziału na grupy interesariuszy szczególnie istotne dla organizacji tego typu, tj. darczyńców, wolontariuszy, media oraz samorząd terytorialny. Elementy witryny WWW składające się na użyteczność informacji przedstawiono szczegółowo w tabeli 1. Bodźce do ponownego odwiedzania witryny internetowej stanowią trzeci element budujący potencjał dialogowy witryny WWW. Osoby odpowiedzialne za jej administrowanie powinny tak ją konstruować, aby zachęcała ona użytkownika do regularnych wizyt. Publikowanie aktualności co najmniej raz na 30 dni stanowi w tym przypadku ważną cechę witryny zachęcającą do jej ponownego odwiedzenia. Pozostałe elementy o bardziej „dialogowym” charakterze to forum, „,zęsto zadawane pytania” czy czat-room (tabela 2). Czwarty element budujący potencjał dialogowy witryny WWW to funkcjonalność "interfejsu" użytkownika, bazująca głównie na jej cechach technicznych. Stanowi on warunek wstępny w budowaniu dialogu. Bez jego spełnienia odbiorca, który

\footnotetext{
${ }^{22}$ M. L. Kent, \& M. Taylor: Building dialogic relationships through the World Wide Web. Public Relations Review, 24(3)/1998, s. 321-334.
} 
ma trudności w nawigacji na witrynie WWW, szybko zniechęci się do jej odwiedzania. Użytecznymi cechami w tym przypadku będą takie elementy witryny jak: mapa witryny internetowej, wyszukiwarka czy możliwość wyboru języka witryny internetowej (tabela 1). Kluczowe w tym przypadku jest umożliwienie użytkownikowi poruszania się po witrynie $\mathrm{w}$ jak najszybszy i intuicyjny sposób. Utrzymanie użytkownika na witrynie internetowej organizacji, stanowi piąty element jej potencjału dialogowego. Witryna WWW powinna posiadać cechy, które sprawią, że użytkownik pozostanie na niej przez jak najdłuższy czas (tzw. stickiness). Najczęściej oznacza to dostęp do ważnych informacji na stronie startowej organizacji, jak najkrótszy czas ładowania strony $z$ komputera użytkownika o średniej jakości łącza internetowego czy wyraźne oznaczenie daty publikacji postu (tabela 1). Negatywnie w tym przypadku należy oceniać np. takie elementy na stronie jak obecność agresywnej reklamy, czy obecność linków do stron niekoniecznie związanych z działalnością organizacji (w przypadku organizacji nonprofit łącza do innych witryn internetowych przeniesiono do bodźców do ponownego odwiedzenia, jako cecha podnosząca wiarygodność organizacji, zwłaszcza w kontekście prowadzonej często działalności społecznej). Podsumowując, funkcjonalność "interfejsu" użytkownika, użyteczność informacji, utrzymanie użytkownika na witrynie internetowej, to elementy głównie o charakterze technicznym, pośrednio wpływające na potencjał dialogowy witryny WWW (warunki wstępne w budowaniu dialogu). Z kolei „pętla dialogowa” oraz bodźce do ponownego odwiedzenia witryny to takie jej cechy, które na ten potencjał wpływają bezpośrednio.

Do badań wybrano tylko te organizacje non-profit, które według stanu na 1 stycznia 2015 roku posiadały status organizacji pożytku publicznego (OPP) ${ }^{23}$. Organizacja pożytku publicznego może zostać podmiot, który prowadzi działalność pożytku publicznego zgodnie z art. 4 ustawy z 24 kwietnia 2003 r. o działalności pożytku publicznego i o wolontariacie, nieprzerwanie co najmniej przez 2 lata oraz uzyskała potwierdzenie tego faktu w Krajowym Rejestrze Sądowym (KRS). Wybór tylko takich organizacji non-profit nie był przypadkowy. Po pierwsze posiadanie statusu OPP, wiąże się z pewnymi przywilejami, np. możliwością otrzymywania $1 \%$ podatku od osób fizycznych. Oznacza to, że również poprzez witrynę WWW, organizacja powinna tak zabiegać o względy użytkownika, aby móc uzyskać dodatkowe środki finansowe wynikające z tej podatkowej możliwości. Po drugie status OPP oznacza konieczność prowadzania dokładnej i jawnej sprawozdawczości. Zgodnie bowiem z art. 23 ust. 6 ustawy z 24 kwietnia 2003 o działalności pożytku publicznego i o wolontariacie (Dz. U. z 2014 r., poz. 1118), każda organizacja pożytku publicznego musi zamieścić sprawozdania finansowe oraz sprawozdanie merytoryczne ze swojej działalności w terminie do dnia 15 lipca roku następującego po roku, za który składane są sprawozdania, na stronie internetowej w Systemie Sprawozdań Finansowych i Merytorycznych Organizacji Pożytku Publicznego. Daje to możliwości wglądu w istotne z badawczego punktu widzenia informacje. Organizacja OPP, która w roku obrotowym osiągnęła przychód do $100000 \mathrm{zł}$ (włącznie) jest zobowiązana do zamieszczenia na stronie internetowej urzędu obsługującego ministra właściwego do spraw zabezpieczenia

${ }^{23}$ Wykaz organizacji pożytku publicznego uprawnionych do otrzymania 1\% podatku dochodowego od osób fizycznych za rok 2014, sporządzony zgodnie z art. 27a ust. 5 ustawy z dnia 24 kwietnia 2003 r. o działalności pożytku publicznego i o wolontariacie (Dz.U. z 2014 r., poz. 1118 z późn zm.) 
społecznego, sprawozdanie w formie uproszczonego sprawozdania merytorycznego i sprawozdania finansowego. Z kolei organizacja, która osiągnie przychody powyżej 100 000 zł jest zobowiązania do zamieszczenia pełnego sprawozdania merytorycznego i sprawozdania finansowego. W wykazie OPP według stanu z 1 stycznia 2015 roku znajdowało się 8018 organizacji. Wykorzystując wzór na wielkość próby minimalnej przy populacji skończonej (dla poziomu ufności 0,95 oraz maksymalnemu błędowi $0,05)$, uzyskano minimalną liczebność próby na poziomie 367 podmiotów. Do badań losowo wybrano więc taką liczbę podmiotów - wykorzystując z kolei algorytm Research Randomizer $^{24}$. Następnie, organizacje non-profit sprawdzono pod kątem posiadania własnej witryny internetowej. W większości przypadków, organizacje umieszczały łącze do niej w ogólnie dostępnym w internecie sprawozdaniu merytorycznym. W pozostałych przypadkach wykorzystano w identyfikacji witryny bazę organizacji pozarządowych oraz wyszukiwarkę internetową google.pl. Spośród 367 organizacji non-profit prawie 29\% nie posiadało własnej witryny internetowej (106 organizacji). Do dalszej części badań zakwalifikowało się więc 261 podmiotów.

Do badania witryn WWW wykorzystano kwestionariusz badawczy składający się z 56 pytań, gdzie odpowiedzi kodowane były w następujący sposób: obecność danego elementu kodowano jako 1, zaś jego brak jako 0. Dostęp do witryn internetowych odbywał się z komputerów o ,przeciętnej” prędkości łącza internetowego w podobnych porach dniach, codziennie przez okres 20 dni. Zastosowana procedura miała pozwolić na pomiar czasu ładowania witryny WWW, przede wszystkim uzależniając to od występujących na stronie startowej elementów graficznych, a nie od komputera osoby kodującej. Początkowo przebadano $10 \%$ tych samych witryn internetowych organizacji non-profit celem sprawdzenia wiarygodności osób kodujących (za kodowanie wszystkich witryn WWW odpowiedzialne były 2 osoby). Wykorzystano w tym celu współczynnik Kappa Cohena, który wahał się w przedziale od 0,7 do 1,00 (średnia $=0,87$ ) dla wszystkich 56 elementów wykorzystanych w ankiecie. Uzyskany materiał badawczy poddano standardowej analizie statystycznej wykorzystując miary położenia oraz odchylenie standardowe.

\section{Wyniki badań}

W celu uzyskania odpowiedzi na pierwsze i drugie pytanie badawcze (tzn.: w jakim stopniu organizacje non-profit wykorzystują pięć zasad $w$ budowie potencjału dialogowego witryny internetowej oraz czy organizacje non-profit w projektowaniu witryny internetowej kładą nacisk w większym stopniu na jej elementy techniczne czy te bezpośrednio związane $\mathrm{z}$ potencjałem dialogowym?), elementy składające się na potencjał dialogowy witryny internetowej podzielone zostały na dwie grupy, tj. techniczne, które obejmowały funkcjonalność "interfejsu" użytkownika, użyteczność informacji oraz utrzymanie użytkownika na witrynie internetowej organizacji oraz elementy dialogowe. Pierwsze z wymienionych stanowią wstępny warunek w budowie potencjału dialogowego witryny WWW, drugie bezpośrednio się do niego odnoszą.

${ }^{24}$ G. C. Urbaniak \& S. Plous: Research Randomizer, 2013 (Version 4.0) [Computer software]. Retrieved on April 22, 2016, from http://www.randomizer.org/ 
Ponadto, zgodnie z metodyką zaproponowaną przez Taylora i innych ${ }^{25}$, użyteczność informacji może być rozpatrywana zarówno na poziomie ogólnym, jak i w rozbiciu na szczegółowe grupy odbiorców. W badaniach dokonano rozbicia na ogólnych użytkowników, darczyńców, wolontariat, media oraz samorząd terytorialny. Użyteczność w ostatniej z wymienionych grup, tworzyły takie elementy jak: widoczny link współpracy $\mathrm{z}$ samorządem, informacje o zrealizowanych przez organizację zadaniach publicznych zleconych przez JST oraz link do programów współpracy NGOs z samorządem terytorialnym (jednoroczny $i$ wieloletnie). Jednakże uzyskane rezultaty pokazały, że nawet $\mathrm{w}$ przypadku organizacji silnie uzależnionych finansowo od samorządu terytorialnego elementy te praktycznie nie występowały, w związku z tym ta grupa odbiorców została $\mathrm{z}$ dalszej analizy wyeliminowana. Ponadto do pozostałych grup tworzących potencjał dialogowy witryny WWW, do metodyki zaproponowanej przez Taylora i innych dodano elementy nowe, w których działaniu podstawową rolę odgrywa treść generowana przez użytkowników danego serwisu, a które nie były jeszcze powszechnie znane $\mathrm{w}$ roku 2001. Składają się na nie takie elementy jak linki przekierowujące do kanałów social media (Facebook, Twitter, itp.), fora, chatroom-y, czy sklepy on-line.

Uzyskane rezultaty wskazują, że zbiór elementów tworzących techniczną część potencjału dialogowego witryny WWW był przez badane organizacje wykorzystywany dwukrotnie częściej w porównaniu do tych o charakterze stricte dialogowym. Spośród 261 organizacji posiadających własną witrynę internetową łącznie zidentyfikowano 35\% elementów składających się na tą grupę. W przypadku funkcjonalności "interfejsu" użytkownika analizowano obecność na witrynie 7 elementów, w przypadku utrzymania użytkownika na witrynie internetowej organizacji - 4 elementów, a w przypadku użyteczności informacji odpowiednio - 9 dla ogółu społeczeństwa, po 5 dla darczyńców i wolontariatu oraz 4 dla mediów. Potencjalne więc, dla 261 organizacji możnaby było zidentyfikować 8523 elementów. Jednakże w przypadku użyteczności informacji dla wolontariatu analizie poddano jedynie 159 organizacji, które w sprawozdaniu rocznym wskazały, że z tej formy pomocy korzystają (z wolontariatu łącznie korzystało bowiem 214 organizacji, z czego 159 posiadało własną witrynę internetową). Odpowiedź na drugie pytanie badawcze jest więc twierdząca. Projektanci witryn internetowych organizacji non-profit znacznie większy nacisk kładą na jej techniczne elementy w porównaniu do tych, które odnoszą się bezpośrednio do jej potencjału dialogowego. Otrzymane rezultaty są zgodne $\mathrm{z}$ ogólnymi tendencjami obserwowanymi w wynikach badań organizacji non-profit przeprowadzonych $w$ innych krajach (w USA, krajach Afryki, czy innych $)^{26}$. Analizowane witryny internetowe są przede wszystkim źródłem prezentacji tradycyjnych materiałów public relations, będąc odpowiednikiem przede wszystkim cyfrowej broszury informacyjnej, z bardzo niewielkim wykorzystaniem dialogowych możliwości jakie daje Internet. Dodatkowo w porównaniu np. do badań

\footnotetext{
${ }^{25}$ M.L. Kent, M. Taylor \& W. White: The relationship between Web site design and organizational responsiveness to stakeholders. Public Relations Review 29(1)/2003, s. 63-77.

${ }^{26}$ S. Kang, H. E. Norton: Nonprofit organizations' use of the World Wide Web: are they sufficiently fulfilling organizational goals? Public Relations Review 30/2004, s. 279-284; D. Ingenhoff \& A.M. Koelling: The potential of Web sites as a relationship building tool for charitable fundraising NPOs. Public Relations Review 35/2009, s. 66-73; A.M.E. Naudé, J.D. Froneman \& R.A. Atwood: The use of the Internet by ten South African non-governmental organizations - a public relations perspective, Public Relations Review 30/2004, s. 87-94.
} 
szwajcarskich organizacji non-profit ${ }^{27}$, elementy techniczne wykorzystywane przy projektowaniu witryny internetowej wykorzystywane były na wyraźnie mniejszą skalę. Wśród elementów składających się na techniczną część witryny zauważyć można duże zróżnicowanie. Zdecydowanie najczęściej identyfikowano elementy składające się na utrzymanie użytkownika na witrynie internetowej organizacji (61,3\%). Praktycznie w przypadku każdej organizacji czas ładowania strony był krótszy niż 4 sekundy, a ponad $85 \%$ organizacji umożliwiało dostęp do ważnych informacji na stronie internetowej najczęściej w formie zakładki z aktualnościami. Na przeciwnym biegunie znalazła się grupa elementów składająca się na użyteczność informacji dla wolontariatu. W przypadku aż 122 organizacji spośród 159, które w oparciu o dane ze sprawozdań rocznych korzystały $\mathrm{z}$ wolontariatu $\mathrm{i}$ posiadały własną witrynę internetową nie zidentyfikowano żadnego elementu składającego się na tą grupę $(76,7 \%$.). Lącznie dla tej grupy rozpoznano niecałe $11 \%$ elementów ją tworzących. Wyróżnić można zaledwie 15 organizacji, których witryny zawierały więcej niż 4 elementy składające się na ten zbiór (max. można było zidentyfikować 5 elementów). W przypadku użyteczności informacji dla ogółu społeczeństwa pula elementów składających się na ten zbiór wykorzystana została połowicznie $(49,1 \%)$. W tej grupie prawie $87 \%$ organizacji umożliwiało dostęp użytkownikowi witryny internetowej do historii organizacji, $85 \%$ organizacji na stronie startowej przedstawiało swoje logo, a 66\% zapewniało dostęp do statutu organizacji. Jedynie $14,6 \%$ organizacji (stowarzyszeń) umieszczało na swojej witrynie WWW opcję umożliwiającą wypełnienie deklaracji członkowskiej. W przypadku pozostałych trzech grup tworzących techniczne elementy witryny internetowej, tj. funkcjonalność "interfejsu" użytkownika, użyteczność informacji dla darczyńców oraz użyteczność informacji dla mediów, ilość zidentyfikowanych elementów była podobna (odpowiednio - 24,0\%, 28,6 i 26,0\%). W przypadku funkcjonalności ,interfejsu” użytkownika, każda organizacja non-profit posiadała przynajmniej 1 element składający się na tą grupe, choć jedynie wśród 3 rozpoznano więcej niż 4 elementy (max. można było zidentyfikować 7 elementów). Aż 77 organizacji z 261 posiadających własną witrynę internetową nie posiadało żadnego elementu składającego się na użyteczność informacji dla darczyńców (29,5\%), 5 witryn internetowych posiadało wszystkie 5 elementów, a w przypadku użyteczności informacji dla mediów $23,4 \%$ organizacji nie posiadało żadnej cechy składającej się na tą grupę. Jedynie 3 organizacje dysponowały witrynami WWW z wszystkimi 4 elementami składającymi się na tą grupę. Zróżnicowanie poszczególnych elementów w tych trzech grupach było duże. W przypadku funkcjonalności "interfejsu" użytkownika praktycznie każda organizacja posiadała łącza do podstron witryny internetowej (98,9\% wskazań). W grupie użyteczności informacji dla darczyńców, 63,2\% organizacji podawało informację o sposobie jej wspierania $\mathrm{w}$ formie wydzielonego linku bądź już na stronie startowej, a w przypadku użyteczności informacji dla mediów notkę biograficzną władz podawało $73,6 \%$ podmiotów. Na przeciwnym biegunie w tych trzech grupach znalazły się takie cechy witryny internetowej, jak: mapa witryny internetowej $(7,3 \%)$, funkcja wyłączania grafiki (wersja „text-only”), funkcja wyboru wariantu graficznego witryny

${ }^{27}$ D. Ingenhoff \& A.M. Koelling: The potential of Web sites as a relationship building tool for charitable fundraising NPOs. Public Relations Review 35/2009, s. 66-73 
internetowej $(4,6 \%)$, skonkretyzowane łącze dla mediów $(7,7 \%)$ czy oficjalne stanowisko organizacji (3,8\%). Szczegółowe dane przedstawiono w tabeli 1.

Tabela 1. Obecność technicznych elementów w tworzeniu potencjału dialogowego witryn internetowych organizacji non-profit

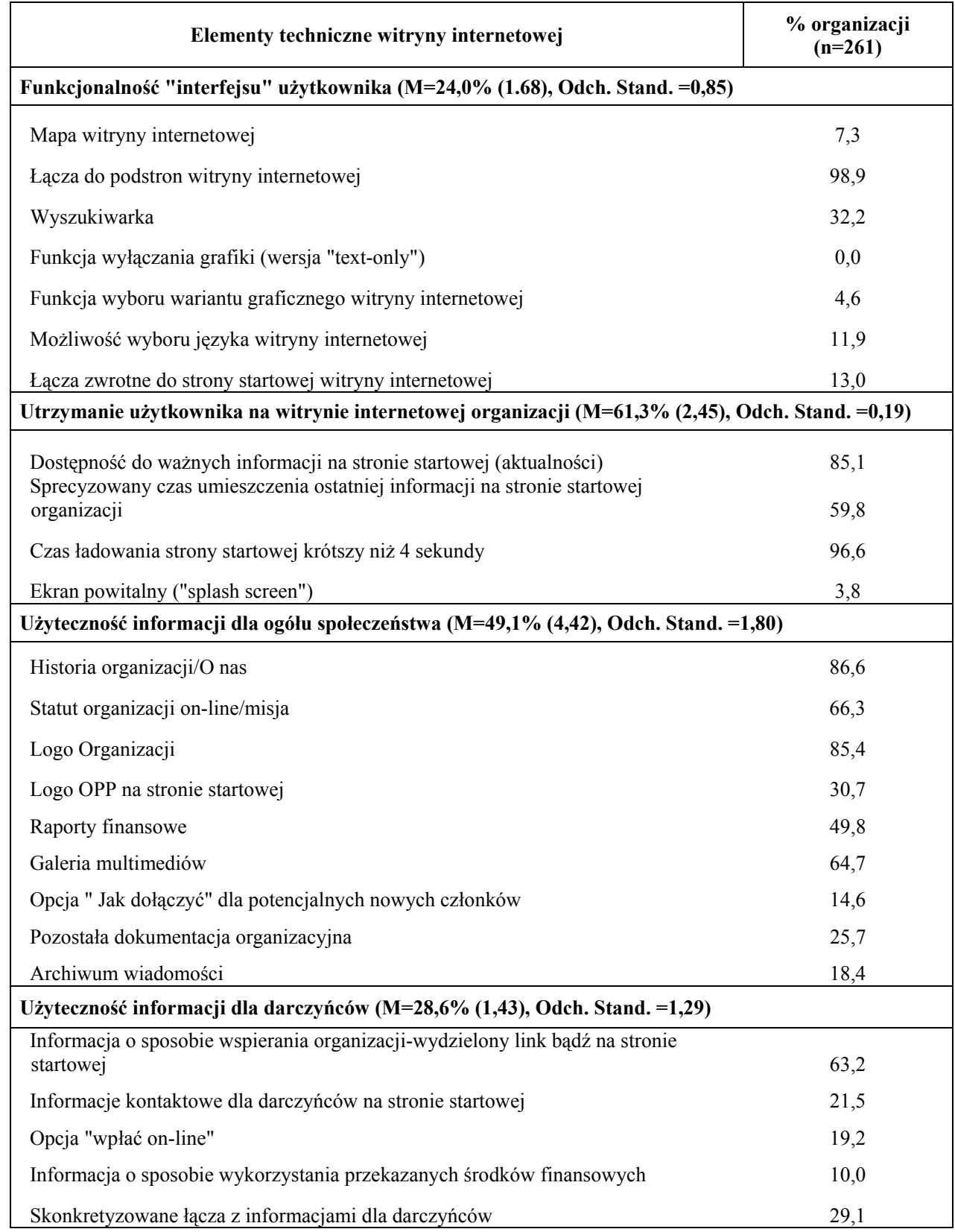




\begin{tabular}{|lc|}
\hline Użyteczność informacji dla wolontariatu (M=10,7\% (0,64), Odch. Stand. =1,34) & \\
\hline Opcja "dołącz do nas" & 12,6 \\
Informacje kontaktowe dla wolontariuszu na stronie startowej & 12,0 \\
Skonkretyzowane łącze z informacjami dla wolontariuszy & 20,7 \\
Opis zasad współpracy & 13,2 \\
Informacja o wezwaniu do działania (call to action) & 5,7 \\
\hline Użyteczność informacji dla media (M=26,0\% (1,04), Odch. Stand. =0,83) & 7,7 \\
\hline Skonkretyzowane łącze dla mediów & 3,8 \\
Oficjalne stanowisko organizacji (speeches) & 73,6 \\
Notka biograficzna władz organizacji & 19,2 \\
\hline Wycinki prasowe & \\
\hline
\end{tabular}

Źródło: opracowanie własne.

Elementy bezpośrednio tworzące potencjał dialogowy witryny internetowej w badanych organizacjach non-profit identyfikowane były dwukrotnie rzadziej niż te o charakterze technicznym. Spośród 261 organizacji posiadających własną witrynę internetową łącznie zidentyfikowano $17 \%$ elementów składających się na tą grupę. Zarówno w grupie ,pętla dialogu”, jak i bodźce do ponownego odwiedzenia witryny internetowej organizacji liczba wskazań była podobna. Co prawda w tej pierwszej grupie zaledwie 6 organizacji non-profit nie posiadało na swojej witrynie żadnego elementu składającego się na tą grupę, ale w głównej mierze zadecydował o tym fakt, że aż 96,9\% organizacji zamieszczało na stronie startowej ogólne informacje kontaktowe. Jedynie 2 organizacje non-profit posiadały więcej niż 4 elementy tworzące tą grupę (max. można było wskazać 7 elementów). Jedynie niecałe 11\% organizacji dawało możliwości użytkownikowi witryny na umieszczenie komentarza do publikowanych informacji. Wynik ten należy oceniać negatywnie zwłaszcza w odniesieniu do organizacji nonprofit, gdzie dla podkreślenia znaczenia realizowanych celów, budowa potencjału dialogowego w przypadku tak taniego narzędzia jak witryna internetowa wydaje się szczególnie istotna. Niestety, znaczenie pozostałych elementów składających się na tą grupę było jeszcze mniejsze (tabela 2). W przypadku drugiego elementu składającego się bezpośrednio na potencjał dialogowy witryny, tj. bodźce do ponownego odwiedzenia witryny internetowej organizacji, organizacje non-profit przy projektowaniu witryny internetowej najczęściej wykorzystywały łącza do innych witryn internetowych $(63,2 \%)$ oraz publikowanie aktualności co najmniej raz na $30 \mathrm{dni}(41,8 \%)$. W grupie tej znalazło się 15 poszukiwanych cech witryny WWW, ale nawet pomimo tego faktu aż 13,8\% witryn internetowych nie posiadało żadnego $\mathrm{z}$ tych elementów. Tylko 1 witryna organizacji non-profit posiadała $8 \mathrm{z} 15 \mathrm{cech}$, a 9 witryn $7 \mathrm{cech}$. Rola takich cech jak forum, często zadawane pytania, podcasty, RSS, chatroom wyraźnie zachęcających do ponownego odwiedzenia witryny internetowej organizacji i bezpośrednio tworzacych jej potencjał dialogowy była traktowana marginalnie. Organizacje non-profit jako kanał social-media wykorzystywały przede wszystkim Facebook. Rola tak popularnego narzędzia w krajach anglosaskich jak Twitter była w polskich organizacjach znikoma. 
Tabela 2. Obecność dialogowych elementów witryn internetowych organizacji non-profit

\begin{tabular}{|l|c|}
\hline \multicolumn{1}{|c|}{ Elementy dialogowe witryny internetowej } & $\begin{array}{c}\text { \% organizacji } \\
\text { (n=261) }\end{array}$ \\
\hline „Pętla dialogu” (M=18,3\% (1.28), Odch. Stand. =0,75) & \\
\hline Opcja umieszczenia komentarza do publikowanych informacji & 10,7 \\
Organizacja odpowiada na komentarze on-line użytkowników & 6,9 \\
Opcja głosowania on-line & 1,5 \\
Opcja wypełniania kwestionariusza ankiety on-line, konkursy & 2,7 \\
Możliwość subskrypcji newslettera & 5,8 \\
Blogi/video blogi & 3,8 \\
Ogólne informacje kontaktowe na stronie startowej & 96,9 \\
\hline Bodźce do ponownego odwiedzenia witryny internetowej organizacji (M=16,4\% (2,46), \\
Odch. Stand. =1,89) & 6,5 \\
\hline Forum & 3,1 \\
Często zadawane pytania(FAQ) & 1,9 \\
Opcja dodawania do ulubionych & 63,2 \\
Łącza do innych witryn internetowych & 22,2 \\
Kalendarz wydarzeń & 30,6 \\
Pliki do pobrania (audio, video, pdf itp.) & 8,8 \\
Udostępnianie informacji na prośbę (np. przez e-mail czy zwykłą pocztę) & 41,8 \\
Publikacja aktualności co najmniej raz na 30 dni & 3,4 \\
Podcasty & 7,3 \\
RSS (Czytnik kanałów) & 1,1 \\
Chat-room & 12,3 \\
Opcja rejestracji jako stały użytkownik witryny internetowej & 37,5 \\
Przekierowanie z witryny internetowej na Facebook & 3,1 \\
Przekierowanie z witryny internetowej na Twitter & 3,4 \\
Sklep on-line & \\
\hline Żo: & \\
\hline
\end{tabular}

Źródło: opracowanie własne.

Trzecie pytanie badawcze dotyczyło rodzaju użytkownika, do którego skierowana jest główna uwaga przy projektowaniu witryny internetowej organizacji non-profit. Specyfika funkcjonowania tego typu organizacji, skutkuje, iż użytkownicy ich witryn internetowych mogą być bardzo zróżnicowani, obejmując zarówno tych o charakterze ogólnym, jak i darczyńców, członków organizacji, wolontariuszy, media, czy samorząd terytorialny. Uzyskane wyniki badań wskazuja, że projektanci witryn internetowych przy ich tworzeniu nie kierują się potrzebami konkretnej grupy odbiorców, ale główną 
uwagę skupiają na użyteczności informacji dla ogółu użytkowników (49,1\% wszystkich elementów składających się na tą grupę). Obecność konkretnych informacji dla darczyńców i mediów była w obu grupach na zbliżonych poziomie (tabela 1), choć w przypadku tej drugiej o tym wyniku zadecydowała przede wszystkim informacja na stronie o władzach organizacji, która może stanowić też informację dla ogółu jej użytkowników. $Z$ kolei najczęściej podawaną informacją dla darczyńców była ta o sposobie wspierania organizacji w formie wydzielonego linku na stronie startowej $(63 \%$ organizacji posiadających witrynę internetowa). Jednakże, wydaje się, że tak istotny element funkcjonowania organizacji non-profit powinien być na stronie startowej mocniej akcentowany. Dziwi fakt, że organizacje w bardzo małym stopniu kierowały skonkretyzowane informacje dla wolontariuszy, mimo że duża grupa organizacji z tej formy współpracy korzystała (58,3\% w sprawozdaniach merytorycznych wskazywała na taką formę pomocy). Należy również podkreślić, że analizowane witryny internetowe organizacji non-profit nie posiadały tych elementów, które bezpośrednio odnosiłyby się do samorządu terytorialnego. Fakt ten może budzić niepokój zważywszy, że często samorząd terytorialny w istotny sposób tworzy ich budżet, a ponadto organizacje nonprofit oraz samorząd terytorialny mają ustawowy obowiązek tworzenia jednorocznych i wieloletnich programów współpracy ${ }^{28}$.

\section{Wnioski}

Komunikacja sieciowa oraz działalność public relations organizacji non-profit jest zjawiskiem stosunkowo rzadko opisywanym w polskiej literaturze naukowej. Celem badań było lepsze zrozumienie jak organizacje pożytku publicznego projektując stronę WWW biorą pod uwagę te jej elementy, które ułatwiają komunikację dialogową między użytkownikiem witryny a organizacją. Pierwsze pytanie badawcze dotyczyło stopnia, w jakim organizacje non-profit wykorzystują pięć zasad w budowie potencjału dialogowego witryny internetowej. Uzyskane rezultaty badań wskazuja, że stopień ten jest niewielki, zwłaszcza w odniesieniu do elementów bezpośrednio tworzących potencjał dialogowy witryny internetowej. Już sam fakt, że prawie 30\% organizacji nonprofit nie posiada własnej witryny internetowej należy oceniać negatywnie (wśród 106 takich organizacji, znalazły się dwie których przychody przekraczały 5 mln złotych oraz 9 z przychodami mieszczącymi się $\mathrm{w}$ przedziale pomiędzy 1 a 5 milionami złotych). Wydawać by się mogło, że wykorzystanie tak taniego narzędzia public relations, zwłaszcza w odniesieniu do organizacji mających możliwość uzyskania 1\% podatku dochodowego od osób fizycznych, będzie znacznie większe. Również skala wykorzystania elementów pośrednio budujących środowisko dialogowe (techniczne) nie była duża ( $35 \%$ wszystkich elementów składających się na tą grupę). W tej grupie najczęściej wskazywano na elementy, które witrynie internetowej nadawały charakter jedynie cyfrowej broszury informacyjnej np. dostępność statutu organizacji, logo organizacji, historia organizacji, notka biograficzna władz organizacji, publikowanie aktualności bez możliwości ich komentowania czy krótki czas ładowania. Również w minimalnym tylko stopniu stowarzyszenia i ich witryny internetowe posiadały opcję

${ }^{28}$ Art. 5a ustawy z dnia 24 kwietnia 2003 r. o działalności pożytku publicznego i o wolontariacie (Dz.U. 2003 Nr 96 poz.873) 
"Jak dołączyć" dla potencjalnych nowych członków $(14,6 \%)$ oraz opcję "dołącz do nas" $\mathrm{w}$ przypadku organizacji korzystających $\mathrm{z}$ wolontariatu $(12,6 \%)$. Po uwzględnieniu faktu, że użytkownik witryny nie ma praktycznie możliwości subskrypcji newslettera $(5,8 \%)$, stwierdzić można, że badane organizacje non-profit projektując ten kanał komunikacji w minimalnym tylko zakresie kierują się interesem potencjalnego członka czy wolontariusza. Ponadto, jedynie co dziesiąte stowarzyszenie posiadało opcję rejestracji dla stałego użytkownika witryny internetowej, w związku z tym treści skierowanych do tej grupy odbiorców również było bardzo niewiele. $\mathrm{W}$ badaniach zidentyfikowano jedynie kilka organizacji, których witryny cechował wysoki poziom potencjału dialogowego. $\mathrm{W}$ przypadku jednej organizacji posiadała ona prawie $68 \%$ wszystkich elementów, a w przypadku 3 organizacji - nieco ponad $67 \%$. Wyraźnie dystansowały one pozostałe organizacje non-profit. Następna w kolejności tych elementów na stronie posiadała niecałe 54\%. Nawet w przypadku tych czterech organizacji zauważyć można tendencję obserwowaną $\mathrm{W}$ pozostałych trzystu sześćdziesięciu trzech. Elementy witryny bezpośrednio dialogowe oscylowały wokół $50 \%$ łącznej ich puli (10-11 z 22 poszukiwanych cech), natomiast elementy techniczne będące wstępnym warunkiem dialogowości witryny prawie $80 \%(27-28$ z 34 poszukiwanych cech). Również $\mathrm{w}$ przypadku pozostałych organizacji elementy techniczne stanowiły wyraźną większość. Co warte podkreślenia, wszystkie 4 organizacje związane były z działalnością na rzecz osób niepełnosprawnych (np. Polskie towarzystwo walki z mukowiscydozą czy Stowarzyszenie rodzin chorych na zespół Marfana oraz inne zespoły genetycznie uwarunkowane). W przypadku tylko jednej organizacji jej przychody były w roku 2014 nieznacznie mniejsze od 5 mln złotych, w pozostałych przypadkach wynosiły odpowiednio 300 tysięcy złotych oraz mniej niż 100 tysięcy dla dwóch organizacji. Budowa witryny internetowej ze stosunkowo dużym potencjałem dialogowym, nie musi się więc wiązać z koniecznością poniesienia wysokich nakładów finansowych, a głównym problemem przy jej projektowaniu wydaje się być brak kadry. Można odnieść wrażenie, że analizowane witryny WWW w większości przypadków funkcjonują na prostej zasadzie, że „wypada ją mieć, bo to jest modne". Wyraźnie brakuje świadomości u osób odpowiedzialnych za podejmowanie decyzji $\mathrm{w}$ organizacjach pożytku publicznego jak ważną rolę odgrywa obecnie public relations w budowaniu relacji. W literaturze przedmiotu wyraźnie podkreśla się, że nie powinno ono być wykorzystywane jedynie jednokierunkowo. Internet i własna witryna WWW wydaje się w budowaniu relacji narzędziem doskonałym, jednak dopiero zrozumienie nowej roli public relations pozwoli w pełni ten potencjał wykorzystać. Autorzy celowo nie podkreślają znaczenia wiedzy technicznej przy tworzeniu i utrzymaniu strony internetowej, gdyż dostępność do tanich i prostych w konstrukcji platform tworzenia własnych witryn WWW jest obecnie bardzo duża (np. wordpress).

Przeprowadzone badania miały pewne ograniczenia. Objęto nimi bowiem 367 organizacji pożytku publicznego, a w bazie danych znajduje się ich ponad 8 tysięcy. Celem większego uwiarygodnienia uzyskanych wyników rozsądne wydaje się więc zwiększenie liczebności próby badawczej. W przyszłości można również rozszerzyć zakres przeprowadzonych badań na kraje ościenne, celem porównania roli witryn internetowych organizacji non-profit w budowie środowiska sprzyjającego dialogowi. 


\section{Spis literatury}

Bakhtin, M.: The dialogic imagination: four essays by M. M. Bakhtin (C. Emerson \& M. Holquist, Trans.).: University of Texas Press., Austin, Texas 1981;

Blank, M., \& Franklin, E.: Dialogue with preschoolers: A cognitively-based system of assessment. Applied Psycholinguistics, 1(02)/2008.

Bohm, D.: Unfolding meaning: A weekend of dialogue with David Bohm., NY: Routledge New York 1985.

Bokeno, M.: Dialogue at work? What it is and isn't. Development and Learning in Organizations, 21(1)/2007.

Bortree, \& Seltzer: Dialogic strategies and outcomes: an analysis of environmental advocacy groups' Facebook profiles. Public Relations Review, 35/2009.

Buber, M: I and Thou: Continuum Publishing Group Inc., 2004.

Cutlip, S. M., Center, A. H., \& Broom, G. M. (2006). Effective public relations (9th ed.). Upper Saddle River, N.J.: Prentice Hall.

DiNardo, A. M.: The Internet as a crisis management tool: A critique of banking sites during Y2K. Public Relations Review, 28/2002.

Esrock, S. L., \& Leichty, G. B.: Organization of corporate Web pages: Publics and functions. Public Relations Review, 26/2000.

Gadamer, H.-G.: Dialogue and dialectic: eight hermeneutical studies on Plato (P. C. Smith, Trans.)., CT: Yale University Press, New Haven 1980a.

Gordon J., Berhof S.: University websites and dialogic features for building relationships with potential students, Public Relations Review, 35/2009.

Greer, C. F., \& Moreland, K. D.: United Airlines' and American Airlines' online crisis communication following the September 11 terrorist attacks. Public Relations Review, 29/2003.

Grönroos, C.: The relationship marketing process: communication, interaction, dialogue, value. The Journal of Business and Industrial Marketing, 19(2)/2004.

Grunig, J. E.: Organizations, environments and models. Public Relations Research and Education, $1(1) / 1984$.

Gustafson, R. L., \& Thomsen, S. R.: Merging the teaching of public relations and advertising onto the information superhighway. Public Relations Quarterly, 41(1)/1996.

Herzberg B. \& Wright, A.: The public-private dialogue handbook: a toolkit for business [sic] environment reformers, 2006, Retrieved from http://www.publicprivatedialogue.org/tools/PPDhandbookC7.pdf

Hinson, R.E., van Zyl H., Agbleze S.,: An interrogation of the dialogic potential of insurance firm websites in Ghana, Information Development 1-11/2013.

Ingenhoff, D., \& Koelling, A. M.: The potential of Web sites as a relationship building tool for charitable fundraising NPOs. Public Relations Review 35/2009.

Kang S., Norton H. E.: Nonprofit organizations' use of the World Wide Web: are they sufficiently fulfilling organizational goals? Public Relations Review 30/2004.

Kent, M. L., \& Taylor, M.: Building dialogic relationships through the World Wide Web. Public Relations Review 24(3)/1998.

Kent, M. L., Taylor, M., \& White, W.: The relationship between Web site design and organizational responsiveness to stakeholders. Public Relations Review 29(1)/2003.

Lord, S. A.: Meditative dialogue: A tool for engaging students in collaborative learning processes. Journal of Family Therapy 29(4)/2007.

Lovejoy K., Saxton G.D.: Information, Community, and Action: How Nonprofit Organizations Use Social Media, Journal of Computer-Mediated Communication Vol. 17/2012.

Lovejoy K., Waters R. D., Saxton G. D.: Engaging stakeholders through Twitter: How non-profit organizations are getting more out of 140 characters or less, Public Relations Review vol. $38(2) / 2012$. 
McAllister, S., \& Taylor, M.: Community college Web sites as tools for fostering dialogue. Public Relations Review 33/2007.

Morrell, K.: Socratic dialogue as a tool for teaching business ethics. Journal of Business Ethics 53(4)/2004.

Naudé, A. M. E., Froneman, J. D., \& Atwood, R. A.: The use of the Internet by ten South African non-governmental organizations - a public relations perspective, Public Relations Review 30/2004.

Park H., Reber B.H.: Relationship building and the use of Web sites: How Fortune 500 corporations use their Web sites to build relationships, Public Relations Review 34/2008.

Pieczka, M: Public relations as dialogic expertise? Journal of Communication Management $15(2) / 2011$.

Podnar, K., \& Golob, U.: Reconstruction of public relations history through publications in Public Opinion Quarterly. Management 13(1)/2009.

Post, J. E., Preston, L. E., \& Sauter-Sachs, S.: Redefining the corporation: Stakeholder management and organizational wealth., CA: Stanford University Press, Stanford 2002.

Rogers, C. R.: On becoming a person : a therapist's view of psychotherapy.: Constable \& Company, London 1961.

Rybalko S., Seltzer T.: Dialogic communication in 140 characters or less: How Fortune 500 companies engage stakeholders using Twitter, Public Relations Review Vol. 36 (4)/2010.

Taylor, M., Kent, M. L., \& White, W. J.: How activist organizations are using the Internet to build relationships, Public Relations Review,27(3)/2001.

Theunissen P., , Wan Noordin W.: Revisiting the concept "dialogue" in public relations, Public Relations Review, 38/2012.

Ustawy z 24 kwietnia 2003 o działalności pożytku publicznego i o wolontariacie (Dz. U. z 2014 r., poz. 1118),

Van der Merwe, R., Pitt, L., \& Abratt, R.: Stakeholder strength: PR survival strategies in the Internet age. Public Relations Quarterly 50(1)/2005.

\section{Summary}

The current range and importance of the Internet, gives unprecedented possibilities concerning building relationships between stakeholders of nonprofit organizations. Therefore, the purpose of this article is to identify the way how public benefit organizations (PBO) use websites to building dialogic potential with their public. Using a modified Kent and Taylor's dialogic principles a content analysis of 367 Public Benefit Organizations was conducted The study shows, that nonprofit organizations only to small extent use five principles in building the dialogic potential of their websites (in particular elements directly creating dialogic potential). A clear lack of awareness of those responsible for making decisions in public benefit organizations is visible concerning the important role played by public relations in building relationships and the role of Internet especially.

Key words: public benefit organizations, dialogue, relationships, Internet,

Informacje o autorach:

Marian Oliński

Uniwersytet Warmińsko-Mazurski w Olsztynie

Katedra Organizacji i Zarządzania

ul. R. Prawocheńskiego 3

10-720 Olsztyn

olinski@uwm.edu.pl 
Piotr Szamrowski

Uniwersytet Warmińsko-Mazurski w Olsztynie

Katedra Organizacji i Zarządzania

ul. R. Prawocheńskiego 3

10-720 Olsztyn

peters6@wp.pl 